\title{
Value Engineering Study for Closing Waste Packages Containing TAD Canisters
}

Scott Allen

Mike Berry

Mark Borland

Michael Clark

Alison Conner

Kevin Croft

Tim McJunkin

Al Ogurek, BSC

Dave Pace
Mike Rice, BSC

Linda Seward

Colleen Shelton-Davis

Rod Shurtliff

Kevin Skinner

Herschel Smartt

Derek Wadsworth

Art Watkins

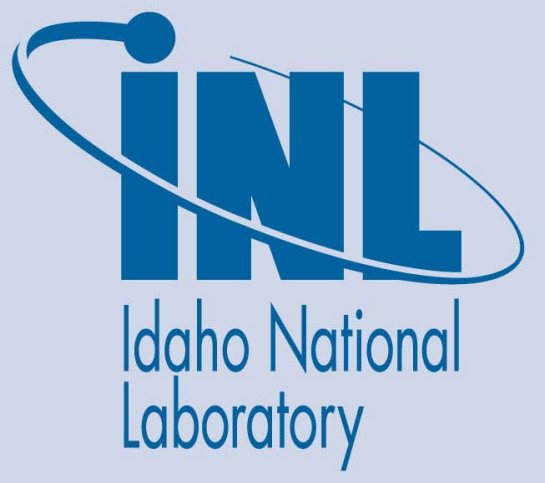

\section{November 2005}

The INL is a U.S. Department of Energy National Laboratory operated by Battelle Energy Alliance 
INL/EXT-05-00960

\title{
Value Engineering Study for Closing Waste Packages Containing TAD Canisters
}

\author{
Scott Allen \\ Mike Rice, BSC \\ Mike Berry \\ Linda Seward \\ Mark Borland \\ Colleen Shelton-Davis \\ Michael Clark \\ Rod Shurtliff \\ Alison Conner \\ Kevin Skinner \\ Kevin Croft \\ Herschel Smartt \\ Tim McJunkin \\ Derek Wadsworth \\ Al Orgurek, BSC \\ Art Watkins \\ Dave Pace
}

November 2005

\section{Idaho National Laboratory \\ Idaho Falls, Idaho 83415}

Prepared for the

U.S. Department of Energy

Office of Civilian Radioactive Waste Management

Under DOE Idaho Operations Office

Contract DE-AC07-05ID14517 
Value Engineering Study for Closing Waste Packages Containing TAD Canisters

INL/EXT-05-00960

November 2005

Approved by
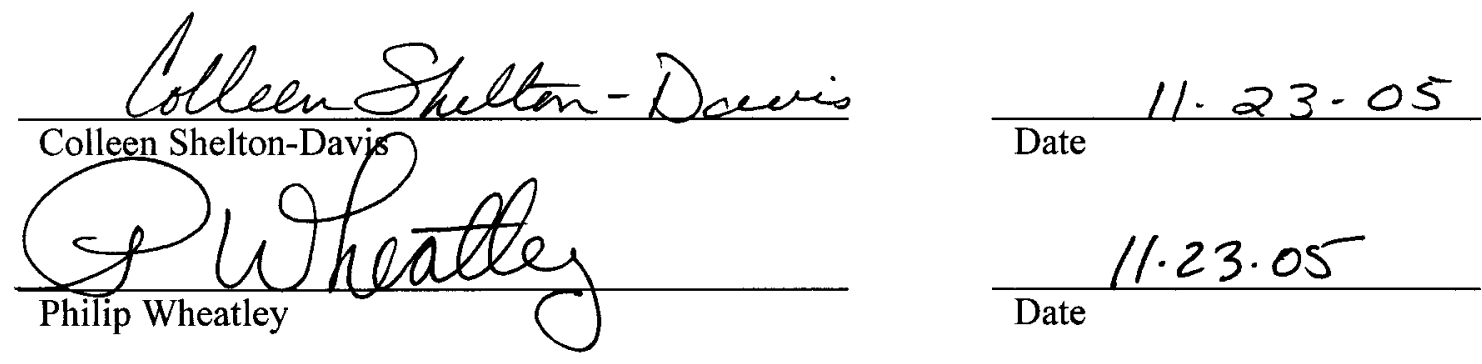


\begin{abstract}
The Office of Civilian Radioactive Waste Management announced their intention to have the commercial utilities package spent nuclear fuel in shielded transportable, ageable, and disposable containers prior to shipment to the Yucca Mountain repository. This will change the conditions used as a basis for the design of the waste package closure system. The environment is now expected to be a low radiation, low contamination area. A value engineering study was completed to evaluate possible modifications to the existing closure system using the revised requirements. Four alternatives were identified and evaluated against a set of weighted criteria. The alternatives are (1) a radiation-hardened, remote automated system (the current baseline design); (2) a nonradiation-hardened, remote automated system (with personnel intervention if necessary); (3) a nonradiation-hardened, semi-automated system with personnel access for routine manual operations; and (4) a nonradiation-hardened, fully manual system with full-time personnel access. Based on the study, the recommended design is Alternative 2, a nonradiation-hardened, remote automated system. It is less expensive and less complex than the current baseline system, because nonradiation-hardened equipment can be used and some contamination control equipment is no longer needed. In addition, the inclusion of remote automation ensures throughput requirements are met, provides a more reliable process, and provides greater protection for employees from industrial accidents and radiation exposure than the semi-automated or manual systems. Other items addressed during the value engineering study as requested by OCRWM include a comparison to industry canister closure systems and corresponding lessons learned; consideration of closing a transportable, ageable, and disposable canister; and an estimate of the time required to perform a demonstration of the recommended closure system.
\end{abstract}




\section{EXECUTIVE SUMMARY}

In October 2005, the Office of Civilian Radioactive Waste Management (OCRWM) announced its intention to include the use of transportable, ageable, and disposable (TAD) canisters for acceptance of bare spent nuclear fuel from the utilities. Under the previous plan, spent fuel assemblies shipped from utilities would be repackaged at Yucca Mountain into waste packages for disposal in the repository. This approach will require the utilities to place spent nuclear fuel into the TAD canisters at the reactor sites. When the TAD canisters are received at Yucca Mountain, they will be loaded directly into the waste packages for final disposal. On November 1, 2005, the OCRWM requested that a value engineering study be performed to determine how, or if, the waste package closure system technology that was already developed would change based on the use of TAD canisters at the repository.

The Idaho National Laboratory (INL) and the Bechtel SAIC Company, LLC (BSC) staff participated in the value engineering study on November 7-10, 2005. BSC contracted INL to design the closure system for the waste packages based on radiation and contamination expected with disposal of bare spent nuclear fuel. Value engineering process was facilitated by Certified Value Specialists and followed the International Society of Value Engineers-approved Job Plan. Information was presented on the background of the project, including the requirements and experience in industry. This information was used to generate the functions that would be analyzed by the team to develop alternative approaches. It was assumed that the presence of a TAD canister would reduce the radiation in the closure cell to a level that nonradiation-hardened equipment would be acceptable $(<40 \mathrm{mrem} / \mathrm{hr})$. Four alternatives were identified and evaluated against a set of weighted criteria developed by the team. The four alternatives are (1) a radiation-hardened, remote automated system (the current baseline); (2) a nonradiation-hardened, remote automated system (with personnel intervention if necessary); (3) a semi-automated system with personnel access for routine manual operations; and (4) a nonradiation-hardened, fully manual system with full-time personnel access. All four systems are capable of performing the closure operations under the new requirements but not necessarily within the short cycle time required of the baseline design.

The optimum choice is the second alternative (nonradiation-hardened, remote automated). It is less expensive and less complex than the current baseline system because some support equipment is no longer needed. In addition, the inclusion of full remote automation ensures throughput requirements are met, provides a more reliable system, and provides greater protection for employees from industrial accidents and radiation exposure than the semi-automated or manual systems.

OCRWM also requested that the following specific questions be considered as part of the value engineering study.

1. Is remote radiation-hardened welding equipment required?

It was determined that nonradiation-hardened equipment could be used to close the waste packages, assuming that the use of a shielded TAD canister reduces the radiation field in the closure cell to an acceptable level $(<40 \mathrm{mrem} / \mathrm{hr})$.

2. How does our approach compare with similar canisters in the industry?

Closure of the waste package is significantly more complex than typical canisters. The waste package has three lids made from two materials of varying 
diameters rather than the typical two lids of one material and size. The system must, therefore, be capable of changing wire material and welding parameters during the closure operation. It must also have the flexibility to access varying diameters, included a small central cap over the purge opening. Other complex requirements of the waste package design include the weld joint configuration (full thickness welds versus partial penetration) and more extensive nondestructive examinations (volumetric versus surface inspections only). Industry does not typically have stringent production schedules, whereas Yucca Mountain must meet aggressive throughput requirements. This drives many of the design features that are different from industry, in particular the remote automation.

3. What portions of the INL work that is already completed would be applicable to welding a TAD or waste package loaded with a TAD, and what portions have no further purpose?

The current baseline is applicable to closure of a waste package loaded with a TAD canister. However, nonradiation-hardened equipment is preferred because of reduction in cost and increased availability. In addition, certain specialized equipment could be simplified (glovebox confinement structure) or eliminated (transfer tunnel shielding, master-slave manipulators).

The applicability of the closure system to seal a TAD canister is strongly dependent on the design of the canister. Collaboration between the INL design team and those designing the TAD canister would ensure that the waste package closure system could be used to seal a TAD canister.

4. How quickly could a welding demonstration project occur with a TAD?

Development of the recommended closure system (nonradiationhardened/automated system) will require about 28 months once the project is reinstated. A demonstration with a waste package loaded with a TAD canister could be performed at that time.

5. What lessons learned are available from industry and from the rest of the U.S. Department of Energy (DOE) complex that OCRWM should take into consideration?

A production type facility that has requirements similar to the waste package closure system has not been implemented in industry or DOE. However, experience has shown that remote automation is important to ensure high throughput schedules, minimize personnel exposure, and improve quality. Semi-automated welding with manual inspection proved to be time and labor intensive on the Three Mile Island fuel repackaging project and the Naval Reactors Facility. Through automation of a previously manual system, the INL low-level waste real-time radioscopy system increased productivity. Observations from manual welding projects in the commercial industry reveal significantly more distorted welds than those produced by automated systems.

The nonradiation-hardened, remote automated system meets the requirements for closure of a waste package loaded with a TAD canister. It simplifies the existing system where applicable while minimizing redesign efforts and still meeting the reliability and throughput needs of Yucca Mountain. 


\section{CONTENTS}

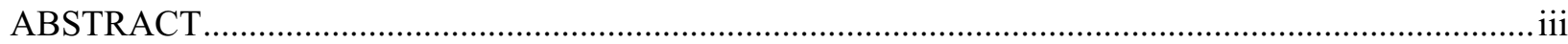

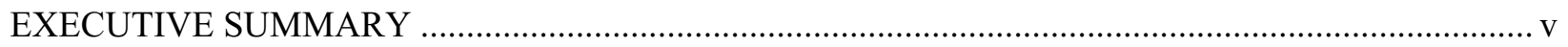

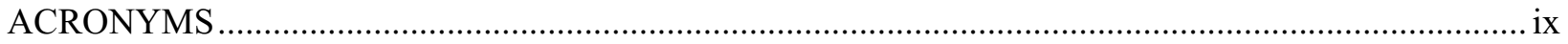

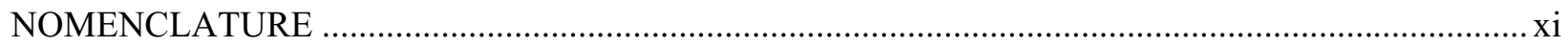

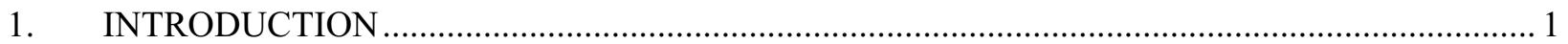

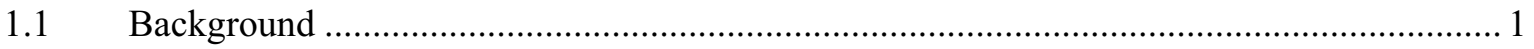

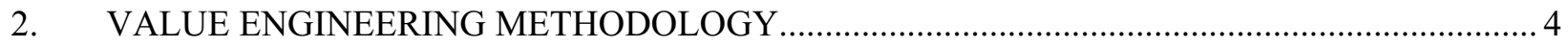

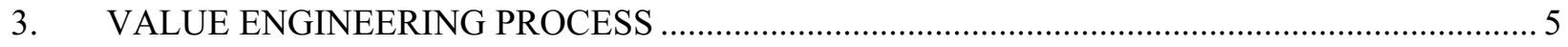

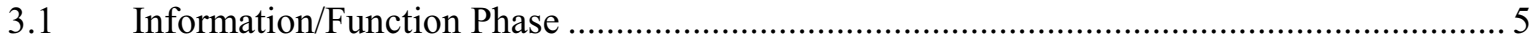

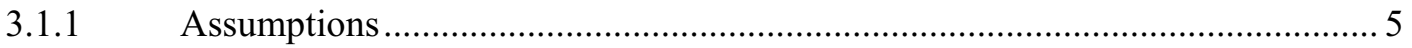

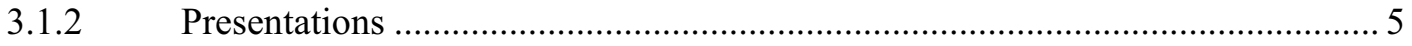

3.1.3 Functions of the Waste Package Closure System with Shielded TAD .............. 7

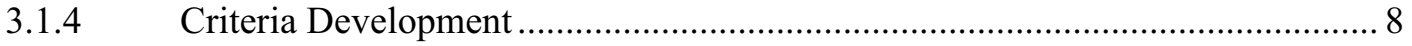

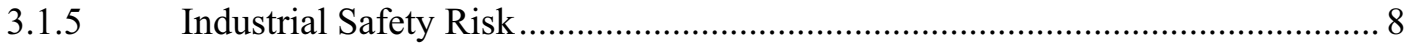

3.1.6 ALARA (As Low As Reasonably Achievable) ......................................... 9

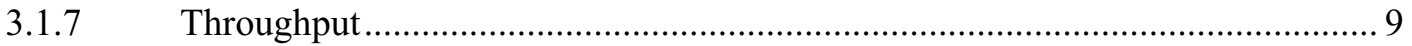

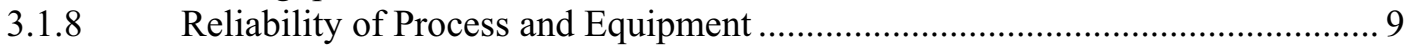

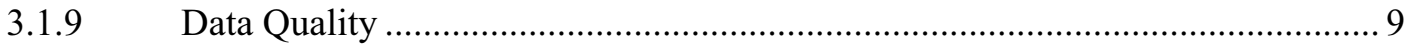

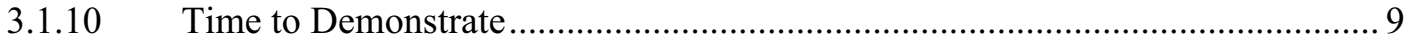

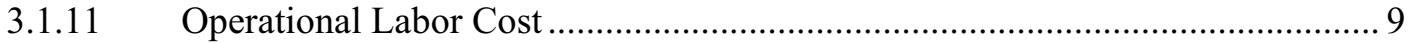

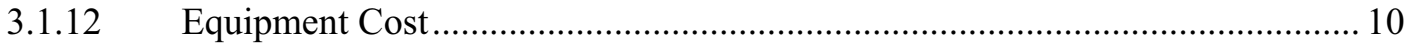

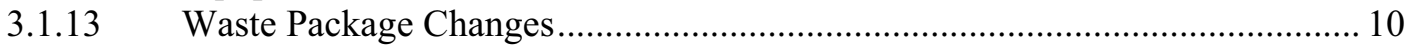

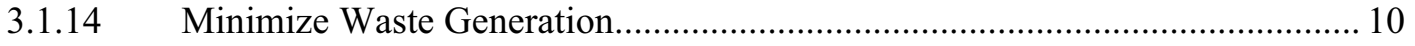

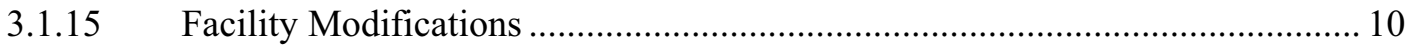

3.2 Alternative Generation — Creativity Phase ................................................................. 10

3.2.1 Alternative 1 - Radiation-Hardened Remote Automated System (Current Baseline Design) .................................................................................. 10

3.2.2 Alternative 2-Nonradiation-Hardened Remote Automated System ................ 12

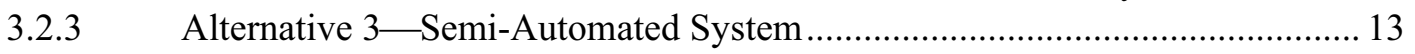

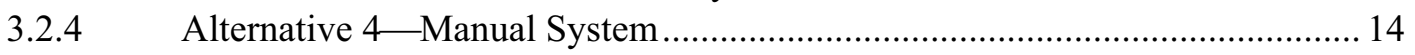

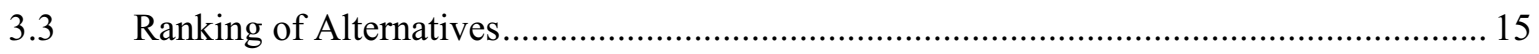

4. RESPONSES TO QUESTIONS FROM OCRWM................................................................... 19

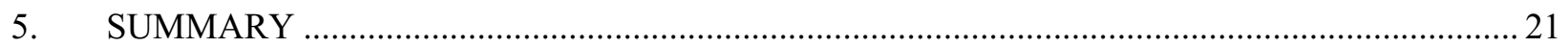




\section{FIGURES}

Figure 1. Illustration of the Yucca Mountain Waste Package Closure System welding a waste package lid in place.

Figure 2. Illustrated cross section of the waste package closure system............................................. 3

\section{TABLES}

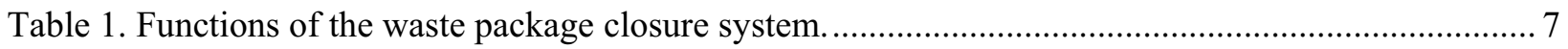

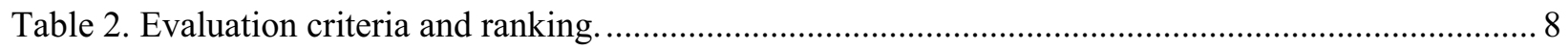

Table 3. Alternative 1: Radiation-hardened remote automated system (current baseline design)............. 11

Table 4. Alternative 2: Nonradiation-hardened remote automated system............................................ 12

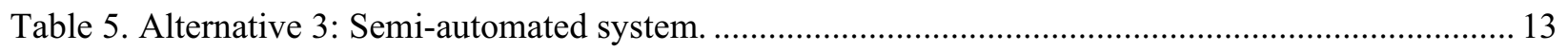

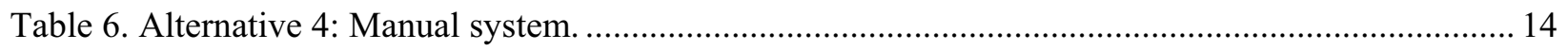

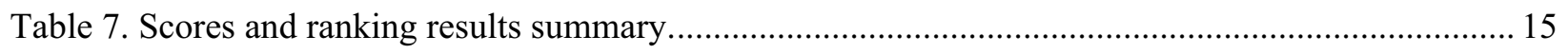

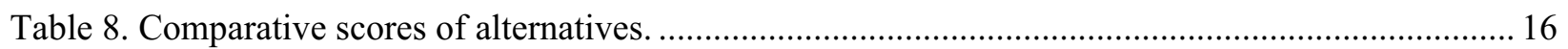




\section{ACRONYMS}

DOE U.S. Department of Energy

INL Idaho National Laboratory

OCRWM Office of Civilian Radioactive Waste

TAD transportable, ageable, and disposable (canister) 


\section{NOMENCLATURE}

Waste package Final disposal container that goes into the Yucca Mountain Repository. The waste package contains the canister or TAD.

Canister

Weld-sealed container that contains spent nuclear fuel or high-level waste, with or without shielding. Canisters are always shipped in a transportation cask.

TAD

Shielded canister that is transportable, ageable, and disposable. TADs are always shipped in a transportation cask.

Eddy current test $\quad$ Surface examination with minimal waste stream.

Liquid penetrant test Surface examination with dye and developer as a waste stream. Also referred to as LP.

Ultrasonic test $\quad$ Volumetric examination of weld with minimal waste. 


\section{Value Engineering Study for Closing Waste Packages Containing TAD Canisters}

\section{INTRODUCTION}

In October 2005, the Office of Civilian Radioactive Waste Management (OCRWM) announced its intention to include the use of transportable, ageable, and disposable (TAD) canisters for acceptance of bare spent nuclear fuel from the utilities. Under the previous plan, spent fuel assemblies shipped from utilities would be repackaged at Yucca Mountain into waste packages for disposal in the repository. This approach will require the utilities to place spent nuclear fuel into the TAD canisters at the reactor sites. When the TAD canisters are received at Yucca Mountain, they will be loaded directly into the waste packages for final disposal. On November 1, 2005, the OCRWM requested that a value engineering study be performed to determine how, or if, the waste package closure system technology that was already developed would change based on the use of TAD canisters at the repository. OCRWM also requested that the value engineering team consider the following types of questions in their review.

1. Is remote radiation-hardened welding equipment required?

2. How does the current approach compare with similar canisters in the industry?

3. What portions of the Idaho National Laboratory (INL) work that is already completed would be applicable to welding a TAD or a waste package loaded with a TAD, and what portions have no further purpose?

4. How quickly could a welding demonstration project occur with a TAD?

5. What lessons learned are available from industry and from the rest of the U.S. Department of Energy (DOE) complex, that the OCRWM should take into consideration?

INL, as the designer of the waste package closure system, participated with the Bechtel SAIC Company, LLC staff in the value engineering study on November 7-10, 2005. The study concluded that the use of TAD canisters would eliminate the need for radiation-hardened equipment and strict contamination control. A recommended alternative is presented as a consideration.

This report includes a description of the value engineering methodology, a process summary from each step in the evaluation, a summary of the results, and a summary section.

\subsection{Background}

The closure system includes all operations required to seal the waste package, backfill the inner vessel with helium, and evaluate the integrity of the welds. Listed below are the high-level system operations performed in closing a waste package.

- Material handling in the closure area

- Welding the lids to the waste package

- Nondestructive examination of the waste package closure welds

- Leak testing the inner vessel of the waste package

- Evacuation and backfill of the inner vessel with helium

- Mitigating the residual surface stresses in the outer lid welds. 
Closing waste packages containing bare fuel requires these operations to be performed in an environment of high radiation and high contamination. There is also a requirement that the cycle time for closing a waste package must be 44 hours or less. Thus, the baseline design is a remotely operated, radiation-hardened system.

Figure 1 shows an illustration of the current waste package closure system design closing a waste package. The top of the waste package is located slightly below a 9-ft-diameter access hole in the floor. Around the hole is a circular bearing that carries two robotic arms that weld simultaneously 180 degrees apart from each other to minimize lid movement during welding and decrease process time. These robotic arms have access to multiple end effectors, so they can also perform the nondestructive examination of the welds and grinding for weld repair. The arms fold back out of the way when a new lid is placed. This feature enhances cycle time by eliminating removal and installation of welding and inspection equipment when the next lid is placed. (A waste package has three lids. The first lid is in place when the waste package arrives. All three lids are welded by the waste package closure system.)

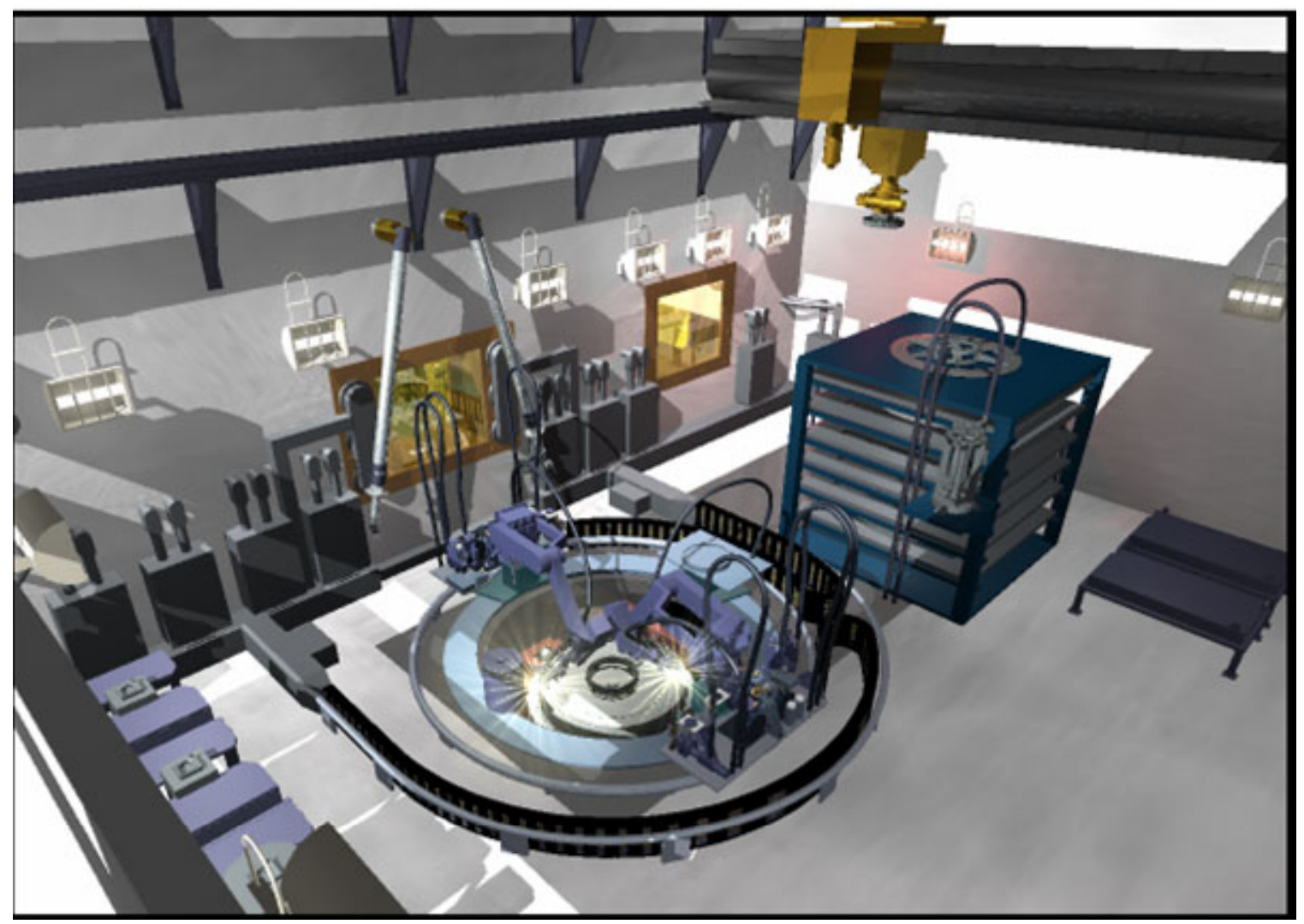

Figure 1. Illustration of the Yucca Mountain Waste Package Closure System welding a waste package lid in place.

Tooling to support the other closure functions are arranged around the perimeter of the closure cell. A robotic crane with telescoping mast, known as the remote handling system, is the primary device used for accurately picking and placing tools and material within the cell.

External to the closure cell, as shown in Figure 2, is a closure operating gallery with work stations to control the remote activities inside the cell. On the opposite side is the closure support area with a large glovebox connected to the cell for servicing the contaminated closure equipment. 
The use of TAD canisters to contain spent nuclear fuel affords alternatives to the existing closure system design. It is assumed use of a TAD canister will allow limited human access near the waste package during closure operations. With this assumption, the baseline conditions are dramatically reduced so closure operations can be performed in a low radiation and low contamination environment. The cycle time of 44 hours is unchanged and remains a challenge with the number of operations to be performed during closure. This value engineering study examines potential design alternatives using these reduced requirements.

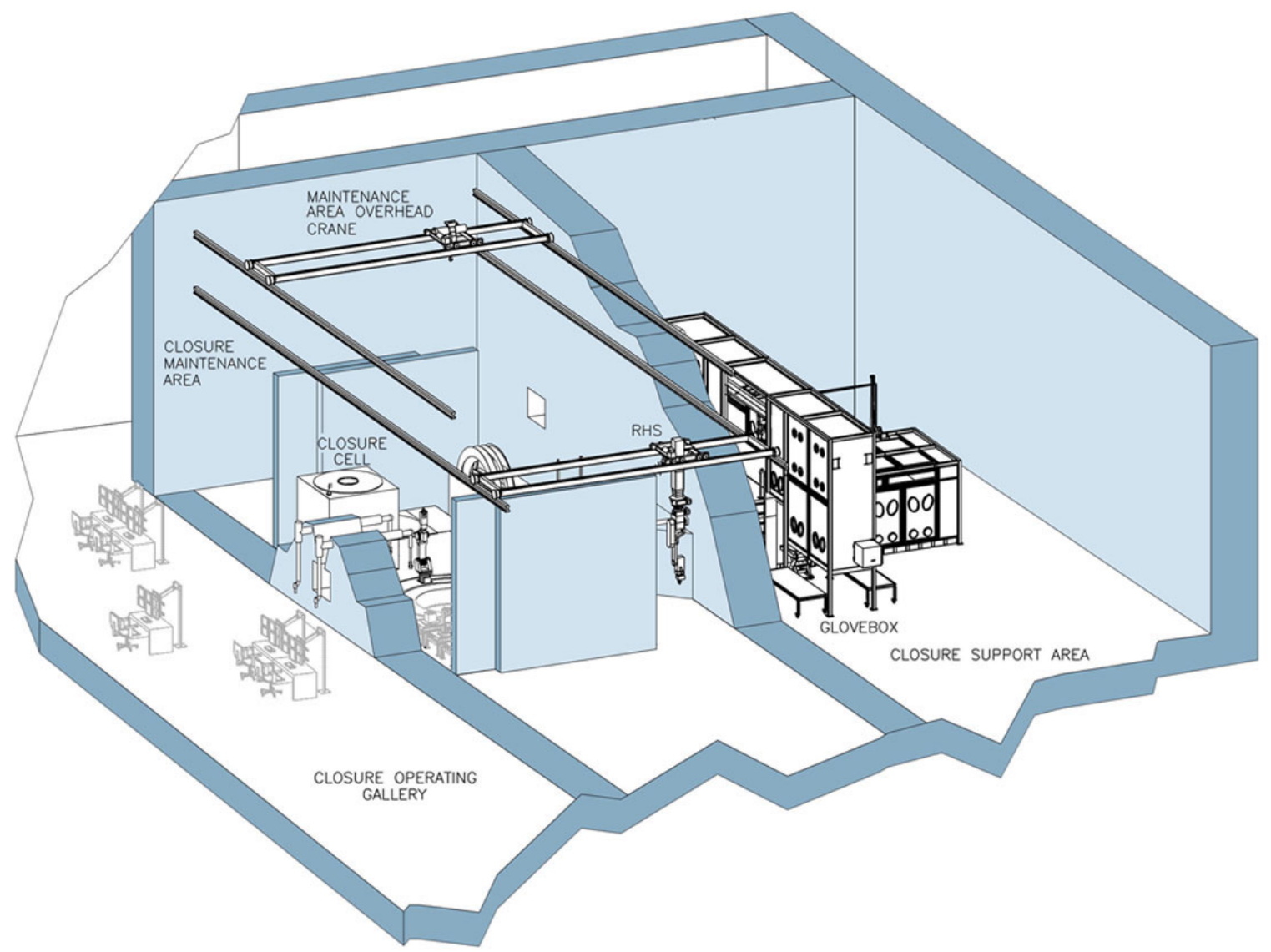

Figure 2. Illustrated cross section of the waste package closure system. 


\section{VALUE ENGINEERING METHODOLOGY}

The fundamental approach of the value engineering process is to challenge what is currently being proposed and to seek alternative approaches to accomplishing the functions. Value engineering is defined as "an organized effort following a structured job plan that is directed at analyzing the functions of systems, equipment, facilities, services, and supplies for the purpose of achieving the essential functions at the lowest life cycle cost consistent with the delivery of required safety, performance, reliability, and quality." It is supported in DOE by OMB A-131 and DOE Orders 413.3 and 430.1B.

This meeting was facilitated by Certified Value Specialists and followed the International Society of Value Engineers-approved Job Plan, including:

- Preparation planning phase

- Information/function phase

- Creativity phase

- Evaluation phase

- Development phase

- Presentation/reporting phase.

Using the Job Plan listed above, information was presented on the background of the project, including the requirements and history to date. This information was used to generate the functions that would be analyzed by the team to develop alternative approaches. Four alternatives were identified and evaluated against a set of weighted criteria developed by the team. A preferred alternative was identified, and the basis of the decision was documented. 


\section{VALUE ENGINEERING PROCESS}

The following subsections present information used by the value engineering team to evaluate which alternative is best suited for the waste package closure system if a TAD canister is used.

\subsection{Information Gathering}

The value engineering team presented information and had a series of discussions concerning the changes to the radiation and contamination requirements and the effects on each operation listed in the introduction. A comparison of the baseline closure system with typical canister closure processes was also presented. During the discussions, a list of assumptions and system functions were identified as a basis for generating the alternatives.

\subsubsection{Assumptions}

1. The waste package closure system footprint will remain the same.

2. Waste package designs and diameters will not change.

3. Cold wire gas tungsten arc welding (GTAW-CW) is a requirement.

4. Stress mitigation will be either laser peening or plasticity burnishing.

5. Routine contamination swipes of the waste package are not needed.

6. Maximum waste package closure time is 44 hours continuous operation (24/7).

7. All pertinent data shall be stored in an electronic database.

8. TAD design (shield plug) and facility features (shielding external to the TAD) will mitigate the radiation levels to approximately $40 \mathrm{mrem} / \mathrm{hr}$ (measured at the top surface of the waste package inner lid in open air) for average fuel loading conditions. The $40-\mathrm{mrem} / \mathrm{hr}$ radiation level allows nonradiation-hardened equipment to be used in the closure process.

9. The sealed TAD will be cleaned to a level of $2200 \mathrm{dpm} / \mathrm{cm}^{2} \cdot \mathrm{sec}$. It is assumed the contamination levels will be low enough for personnel access.

10. The value engineering team considered potential impacts to the Repository design and project costs resulting from any increase in the length of the waste package to accommodate a TAD. The team determined that this aspect of incorporation of a TAD was not within the scope of the WPSC Value Engineering Study.

Bechtel SAIC Company, LLC stated that the 30-Day Preliminary Report for the Critical 1 addresses potential impacts to the repository design relative to increased waste package size. Costs are not specifically addressed but will be captured in the final CD-1 package.

\subsubsection{Presentations}

The following presentations were made to the evaluation team. Salient points that were captured from these presentations are described below. 


\section{Radiation and Contamination}

Design of a TAD canister has not been performed yet, so an assumption had to be made concerning the radiological conditions within the closure cell in order to perform the evaluation. An analysis was performed to determine a basis for estimating the cell conditions. Assuming an average field of $100 \mathrm{Rad} / \mathrm{hr}$ measured at the top surface of the waste package containing no shield plug, a nonradiation hardened system (commercial equipment) would last approximately 45 hours, which is unacceptable. Shielding of 8 inches of steel in the TAD canister would provide enough shielding to reduce the cell radiation field to about $40 \mathrm{mrem} / \mathrm{hr}$. At this exposure level, commercial equipment capable of withstanding $5 \times 10^{3}$ rad total dose (typical of commercial equipment) would last about 14 years. The TAD will be required to meet the transportation contamination requirements, so it should be relatively clean but not be completely free of contamination. It was assumed that the contamination levels would be low enough for personnel access, below $2200 \mathrm{dpm} / \mathrm{cm}^{2} \cdot \mathrm{sec}$.

\section{Leak detection/evacuation backfill}

Most of the leak detection and evacuation/backfill equipment are inherently resistant to radiation (metal construction). Some components could be replaced with nonradiation-hardened alternatives. These components include seals, motors, transducers, and sensors. Low contamination will minimize the need for HEPA filters in both systems. If cell access is allowed, remote disconnects are not needed.

\section{Welding and Nondestructive Examination}

Many components with the welding and nondestructive examination systems are specialized to tolerate the high radiation. These could be replaced with standard, nonradiation-hardened components. Polymer materials, motors, sensors, and cameras are examples. Manual welding and nondestructive examination of the waste package located nominally 12 inches below the floor would be difficult. The likelihood of low quality welding and nondestructive examination is significantly increased using manual processes. Automated welding and nondestructive examination processes increase productivity throughput and data quality.

\section{Material Handling/Maintenance}

Material handling and maintenance is performed with the four systems: the remote handling system, master-slave manipulator, the transfer system, and the glovebox. The remote handling system and transfer system would still be required, but they would not need radiation-hardened components. Minimal contamination would eliminate the need for the master slave manipulators and a glovebox confinement (though some structure would be needed for performing the maintenance functions).

\section{Control and Data Management}

The most significant modification to the Control and Data Management System would be the option of placing electronic equipment within the closure cell. Locating electronic equipment in the closure cell reduces the complexity of cabling and the number of wall penetrations. Collection of archival data using remote automated systems can be accurately referenced to each waste package. 


\section{Industry Practices for Closure Weld Processes}

Commercial spent nuclear fuel canisters are engineered for a design life of 40 to 50 years. The canister confinement boundary typically is limited to a single material type (stainless or carbon steel). Closure of these canisters follows the guideline of the ASME code Section III, Subsection NB or NC. For closure welding of canisters, center pivot welding machines with one torch are typically used. Welding normally involves a two-weld closure, one weld on the inner shield plug and one weld on the outer lid. They perform flat and horizontal welding and most welds are fillet and partial penetration butt welds. Grinding, and preweld and interbead cleaning are performed manually.

Generally, GTAW-CW and GTAW-HW are semi-automated welding processes. Welding and welding setup are performed by personnel in a controlled area. Volumetric examination of closure welds are replaced by layered liquid penetrant and leak test examinations. All nondestructive examinations are performed manually. Nondestructive examinations are usually limited to visual inspection and liquid penetrant or magnetic particle examinations. The latter two processes generate additional wastestreams.

Industry raises the canister to some height above the floor for personnel to perform welding, nondestructive examination and leak testing. In addition, two different types of canisters are used, one for transportation and one for short term storage.

Industry performs a leak test of the purge port cap weld with helium. The purge port plug is not considered the leak boundary. Helium is manually introduced to the purge port cavity using purge needles. Helium pressure levels are only 2 or 3 psig.

\subsubsection{Functions of the Waste Package Closure System with Shielded TAD}

This section identifies a general listing of required functions that are to be performed in the waste package closure cell. These functions are baseline requirements applied to any closure system alternative under consideration. They were listed during the initial phase of the value engineering session in order to provide a basis for evaluation of system alternatives. The list encompasses higher level activities that are envisioned to take place in the waste package closure system. Table 1 identifies the function and an associated commentary on each one.

Table 1. Functions of the waste package closure system.

\begin{tabular}{|l|l|}
\hline \multicolumn{1}{|c|}{ Function } & \multicolumn{1}{c|}{ Commentary } \\
\hline Inert Waste Package & $\begin{array}{l}\text { A process whereby the air inside the waste package is removed } \\
\text { and replaced with an inert gas. }\end{array}$ \\
\hline Leak Test (Inner Lid Seal Weld) & The process of testing inner lid seal welds for leakage. \\
\hline Weld Lids & Welding of the waste package lids on the waste package. \\
\hline Inspect Welds & $\begin{array}{l}\text { The processes associated with inspection of completed welds. } \\
\text { Current inspection methods include visual, ultrasonic, and eddy } \\
\text { current. }\end{array}$ \\
\hline Repair Defects & $\begin{array}{l}\text { The process of repairing weld defects in waste package closure } \\
\text { welds. }\end{array}$ \\
\hline Handle Materials/Equipment & $\begin{array}{l}\text { The processes involved with handling, moving, and } \\
\text { transferring materials and equipment in and around the waste } \\
\text { package closure system area. }\end{array}$ \\
\hline
\end{tabular}


Table 1. (continued).

\begin{tabular}{|l|l|}
\hline \multicolumn{1}{|c|}{ Function } & \multicolumn{1}{c|}{ Commentary } \\
\hline $\begin{array}{l}\text { Control Operations } \\
\text { (control and data management) }\end{array}$ & $\begin{array}{l}\text { Controlling of processes, operations, and equipment within the } \\
\text { waste package closure system and the collection, management, } \\
\text { and storage of data. }\end{array}$ \\
\hline Maintain/Repair Equipment & $\begin{array}{l}\text { This function provides for physical maintenance and repair of } \\
\text { waste package closure system equipment. }\end{array}$ \\
\hline Mitigate Weld Stresses & $\begin{array}{l}\text { The implementation of equipment and processes for } \\
\text { introducing compressive stresses in the outer lid weld and } \\
\text { adjacent base material. }\end{array}$ \\
\hline
\end{tabular}

The functions stated above are required regardless of the alternative considered. Because of their importance to the waste package closure system, they were used in guiding the generation of viable alternatives and the criteria from which the value engineering alternative evaluation was performed.

\subsubsection{Criteria Development}

The value engineering team identified a list of consequential issues related to the overall task sequence of closing a waste package. This list is pertinent, regardless of the process or the environmental conditions encountered during the process. Each issue or criterion was evaluated against the other criteria in the list and ranked with an integer value between 1 and 11 with 11 being the most important criterion.

A minor bias may be introduced to the weighting because of the technical nature of the value engineering team. This bias may tend to shift the assigned weight to a more technical slant versus programmatic. Table 2 .

The criteria, along with the respective ranking and normalized weighting factors, are presented in

Table 2. Evaluation criteria and ranking.

\begin{tabular}{|l|c|c|}
\hline \multicolumn{1}{|c|}{ Criteria } & Rank within the List & Normalized Weight \\
\hline Industrial Safety Risk & 11 & 16.7 \\
\hline ALARA & 10 & 15.2 \\
\hline Throughput & 9 & 13.6 \\
\hline Reliability of Process and Equipment & 8 & 12.2 \\
\hline Data Quality & 7 & 10.6 \\
\hline Time to Demonstration & 6 & 9.1 \\
\hline Operational Labor Cost & 5 & 7.6 \\
\hline Equipment Cost & 4 & 6.0 \\
\hline Waste Packages Changes & 3 & 4.5 \\
\hline Minimize Waste Generation & 2 & 3.0 \\
\hline Facility Modifications & 1 & 1.5 \\
\hline Totals & 66 & $100 \%$ \\
\hline
\end{tabular}

Each of the evaluation criteria are presented in the succeeding sections.

\subsubsection{Industrial Safety Risk}

This criterion considers the relative risk for injuries to workers who maintain the system and perform the required tasks. Each alternative, including the baseline, was graded on the potential for 
worker injury. This criterion includes heat/cold stress, fatigue, ergonomic considerations, etc. A higher score represents a higher level of worker safety as compared to the other alternatives.

\subsubsection{ALARA (As Low As Reasonably Achievable)}

This criterion was used by the value engineering team to evaluate the total amount of radiation exposure expected for all workers during a complete closure cycle. It does not consider how the application of physical or administrative controls might alter the environment (shielding or access control), but rather evaluates the inherent system characteristics that remove opportunities for exposure to radiation and eliminate the risk of potential contamination. A high score indicates the greatest protection against exposure as compared to the other alternatives.

\subsubsection{Throughput}

This criterion evaluates the ability of a proposed waste package closure process to complete all of the process tasks assuming 100\% efficiency. The alternative with the shortest time to close would receive the higher grade for throughput. Also considered is the system availability as affected by preventative and required maintenance. A high score indicates the alternative that would be able to complete more waste package closure cycles in a given time as compared to the other alternatives.

\subsubsection{Reliability of Process and Equipment}

This criterion considers the consistency of continued operation as well as factoring the potential for defects as a result of equipment failure and operator error. Reliability is defined as the probability of the equipment and operators to complete an assigned task without the need for unanticipated intervention or rework. A high score indicates an alternative offering a higher level of confidence in the operation of the system as compared to the other alternatives.

\subsubsection{Data Quality}

This criterion considers the ability and the efficiency of the process to acquire, assimilate, make decisions, record, store, and archive "process pertinent" and "process legal" information. It factors the manner of the collection of data from the bar codes on the waste package to the incorporation of correct and legally defensible waste package closure process data. A high score indicates an alternative offering the highest level of confidence in the integrity of the data.

\subsubsection{Time to Demonstrate}

This criterion evaluates how much elapsed time would be required before a waste package welding demonstration project could occur. It assumes a baseline waste package design and a neutral demonstration cell. It does not factor the relative costs of alternatives into the schedule, but assumes the current level of funding. This criterion does not consider whether a facility would be ready in the same timeframe or the effects of the facility on the demonstration schedule. The highest score indicates the alternative that can demonstrate waste package closure at the earliest date regardless of whether that date is acceptable.

\subsubsection{Operational Labor Cost}

This criterion considers the total cost of labor to close the waste package. This includes all labor input and the corresponding wages from technicians to equipment operators to inspectors. A higher score indicates a greater savings on labor cost as compared to the other alternatives. 


\subsubsection{Equipment Cost}

This criterion considers the total equipment costs associated with a waste package closure alternative. It includes initial equipment cost as well as replacement cost, including replacement throughout the entire life cycle of the closure project. Final disposition cost is not factored. The comparison between initial and lifecycle costs is not factored into the evaluation. A higher score is indicative of a greater savings on lifetime equipment costs as compared to the other alternatives.

\subsubsection{Waste Package Changes}

This criterion compares the waste package closure process alternatives with respect to the changes that would be necessary to the baseline waste package design. These are changes that would be needed to allow or to facilitate operational characteristics of the process. A higher score indicates that a process does not require modification of the baseline waste package design.

\subsubsection{Minimize Waste Generation}

This criterion compares the alternatives with respect to the amount of secondary waste generated by the process. Secondary waste is defined as any material generated by and for the process that requires special handling and disposal, such as personal protective equipment. A higher score indicates an alternative that would generate the smallest amount of waste as compared to the other alternatives.

\subsubsection{Facility Modifications}

This criterion evaluates each alternative on the modifications to a baseline facility that would be necessary to accommodate that alternative. The baseline facility is the current waste package closure cell design. The criterion does not evaluate the merits of a facility designed specifically for a particular process or compare those alternative facility designs against each other. A higher score is indicative of fewer required modifications to the baseline facility to incorporate the process. This criterion tends to favor one alternative because that alternative is designed around the baseline facility.

\subsection{Alternative Generation}

During this phase, the value engineering team identified several alternatives for evaluation against the selected criteria. Actual expected conditions within the closure cell are not known because the TAD canister has not yet been designed. Therefore, an assumption on the environment was made based on the information presented in Section 3.1.2, Part 1. The alternatives were developed assuming the radiation field in the closure cell is less than $40 \mathrm{mrem} / \mathrm{hr}$ and the contamination level is less than 2200 $\mathrm{dpm} / \mathrm{cm} 2 \cdot \mathrm{sec}$.

\subsubsection{Alternative 1 - Radiation-Hardened Remote Automated System (Current Baseline Design)}

The radiation-hardened remote automated system is the current baseline design. It has been designed for operation in high radiation fields and in areas with high contamination. All components are either radiation-hardened, remotely replaceable, or serviceable in the glovebox. Equipment was designed for easy decontamination. Master-slave manipulators mounted next to the process opening and a manipulator attached to the remote handling system are used for material handling and recovery operations. A glovebox is used for most routine maintenance, servicing, and repairs. The system features remote automated deployment of equipment. Control of operations and data collection are also automated from the operating gallery. An annual cell shutdown is scheduled with manned entry for other 
maintenance and repairs. Recovery operations due to off normal events are planned to be performed remotely.

The key design features unique to a specific system function are given in Table 3 .

Table 3. Alternative 1: Radiation-hardened remote automated system (current baseline design).

\begin{tabular}{|c|c|}
\hline System Function & Key Design Features \\
\hline Inert Waste Package & $\begin{array}{l}\text { Filtration built into the inner lid } \\
\text { In-line filtration in the purge and backfill line } \\
\text { Remotely operable quick disconnect for retrieval of tooling }\end{array}$ \\
\hline $\begin{array}{l}\text { Leak Test Inner Lid } \\
\text { Seal Weld }\end{array}$ & $\begin{array}{l}\text { In-line filtration in line with the helium leak detector } \\
\text { Support equipment located in the operating gallery } \\
\text { Automated remote deployment of leak locating sniffer } \\
\text { In-line filtration in sniffer line }\end{array}$ \\
\hline Weld Lids & $\begin{array}{l}\text { End effectors stored on a removable tool tray for servicing in the } \\
\text { glovebox } \\
\text { High weld metal deposition rates }\end{array}$ \\
\hline Inspect Welds & $\begin{array}{l}\text { Nondestructive examination support electronics located in the } \\
\text { operating gallery } \\
\text { End effectors stored on a removable tool tray for servicing in the } \\
\text { glovebox } \\
\text { Precisely locate defects } \\
\text { Automated high speed inspection }\end{array}$ \\
\hline Repair Defects & Programmable automated repairs \\
\hline Handle Materials/Equipment & $\begin{array}{l}\text { Computer controlled remote handling system } \\
\text { Remote handling system manipulator for cell wide recovery } \\
\text { operations } \\
\text { Master-slave manipulators for recovery operations around process } \\
\text { opening } \\
\text { Transfer cart will be used for automated transfer of equipment and } \\
\text { materials }\end{array}$ \\
\hline $\begin{array}{l}\text { Control Operations } \\
\text { (control and data management) }\end{array}$ & $\begin{array}{l}\text { Networked distributed control system with supervisory permissives } \\
\text { provided to each control module } \\
\text { Centralized data collection and storage } \\
\text { Centralized remote control of cell operations } \\
\text { Camera inserts allowing replacement without cell entry } \\
\text { Sealed cabling system }\end{array}$ \\
\hline Maintain/Repair Equipment & $\begin{array}{l}\text { Material transfer cart system with dual shield doors for cell delivery } \\
\text { of materials } \\
\text { Glovebox for contamination control } \\
\text { Glovebox servicing of tool trays } \\
\text { Glovebox maintenance of retrievable tooling } \\
\text { Computer controlled glovebox handling system for tool } \\
\text { manipulation within glovebox } \\
\text { Shielded transition area for personnel cell entry }\end{array}$ \\
\hline Mitigate Weld Stresses & Remotely operable quick disconnect for retrieval of tooling \\
\hline
\end{tabular}




\subsubsection{Alternative 2-Nonradiation-Hardened Remote Automated System}

The nonradiation-hardened remote automated system is tailored to operate in a low radiation and low contamination environment. Items pertaining to contamination control would be removed or modified from the baseline alternative. Less expensive commercial grade equipment is possible because of the low radiation. Component design would not need to consider decontamination features due to the low contamination. Support equipment could be moved into the closure cell simplifying the cabling and wall penetrations. Equipment deployment, operations control, and data collection are automated from a remote location (the operating gallery). A centralized control system and networked distributed control system with supervisory permissives would still be implemented. Off-normal access to the closure cell with the waste package in place would be possible for recovery operations. Routine access into the closure cell regardless of whether there was a waste package present is possible, but not planned with this alternative. Personnel entry would be required for some off normal events.

The key design features unique to a specific system function are given in Table 4 below.

Table 4. Alternative 2: Nonradiation-hardened remote automated system.

\begin{tabular}{|c|c|}
\hline System Function & Key Design Features \\
\hline Inert Waste Package & $\begin{array}{l}\text { Inner lid filtration not required due to lowered contamination levels } \\
\text { In-line filtration in the purge and backfill line not required due to } \\
\text { lowered contamination levels } \\
\text { Remotely operable quick disconnect not required }\end{array}$ \\
\hline Leak Test Inner Lid Seal Weld & $\begin{array}{l}\text { Support equipment could be moved into the closure cell simplifying } \\
\text { the cabling and wall penetrations and removing the need for the } \\
\text { in-line filtration } \\
\text { Reduced maintenance due to lower radiation levels, allowing for } \\
\text { longer material life }\end{array}$ \\
\hline Weld Lids & $\begin{array}{l}\text { End effectors stored on a removable tool tray for servicing } \\
\text { High weld metal deposition rates }\end{array}$ \\
\hline Inspect Welds & $\begin{array}{l}\text { Nondestructive examination support electronics could be located in } \\
\text { the closure cell } \\
\text { End effectors stored on a removable tool tray for servicing } \\
\text { Precisely locate defects } \\
\text { Automated high speed inspection }\end{array}$ \\
\hline Repair Defects & Programmable automated repairs \\
\hline Handle Materials/Equipment & $\begin{array}{l}\text { Remote handling system manipulator not required due to ability for } \\
\text { personnel entry for recovery operations } \\
\text { Master-slave manipulators not required due to ability for personnel } \\
\text { entry for recovery operations } \\
\text { Minimally shielded doors for cell delivery of materials } \\
\text { Transfer cart will be used for automated transfer of equipment and } \\
\text { materials }\end{array}$ \\
\hline $\begin{array}{l}\text { Control Operations } \\
\text { (control and data management) }\end{array}$ & $\begin{array}{l}\text { K-plug and camera inserts not required due to the ability for } \\
\text { personnel entry for maintenance } \\
\text { Sealed cabling system not required }\end{array}$ \\
\hline Maintain/Repair Equipment & $\begin{array}{l}\text { Work tables with direct hand contact for tool tray servicing and } \\
\quad \text { complete system testing } \\
\text { Glovebox containment not required } \\
\text { Personnel entry for maintenance of equipment } \\
\text { Unshielded transition area for personnel cell entry }\end{array}$ \\
\hline Mitigate Weld Stresses & Remotely operable quick disconnect not required \\
\hline
\end{tabular}




\subsubsection{Alternative 3 Semi-Automated System}

The semi-automated system is tailored to operate in a low radiation and low contamination environment. The equipment would be designed with some automation to increase throughput but would essentially be operated locally in the closure cell. Automated data collection would also be performed locally. Items pertaining to contamination control would be removed or modified, as in alternative 2 . Equipment and materials would be deployed with lifting assistance, but deployment would not be automated. The design would no longer have a centralized control system. Routine access into the closure cell regardless of whether there was a waste package present is planned with this alternative.

The key design features unique to a specific system functions are given in Table 5 below.

Table 5. Alternative 3: Semi-automated system.

\begin{tabular}{|c|c|}
\hline System Function & Key Design Features \\
\hline Inert Waste Package & $\begin{array}{l}\text { Inner lid filtration not required } \\
\text { In-line filtration in the purge and backfill line not required } \\
\text { Remotely operable quick disconnect not required due to the ability } \\
\text { for personnel retrieval of tooling }\end{array}$ \\
\hline $\begin{array}{l}\text { Leak Test Inner Lid } \\
\text { Seal Weld }\end{array}$ & $\begin{array}{l}\text { Manually deployed leak locating sniffer } \\
\text { Support equipment could be moved into the closure cell simplifying } \\
\text { the cabling and wall penetrations and removing the need for the } \\
\text { in-line filtration }\end{array}$ \\
\hline Weld Lids & $\begin{array}{l}\text { Local semi-automated welding control } \\
\text { System serviced locally, removable tool trays no longer needed }\end{array}$ \\
\hline Inspect Welds & $\begin{array}{l}\text { Semi-automated (ultrasonic and eddy current examination) and } \\
\text { manual inspection (visual examination) with local operation and } \\
\text { control } \\
\text { System serviced locally, removal tool trays no longer needed }\end{array}$ \\
\hline Repair Defects & $\begin{array}{l}\text { Hand-operated grinder for weld repair } \\
\text { Hand-held vacuum system for swarf collection }\end{array}$ \\
\hline Handle Materials/Equipment & $\begin{array}{l}\text { Computer controlled remote handling system not required, material } \\
\text { handling done with crane with direct operator guidance } \\
\text { Remote handling system manipulator not required due to ability for } \\
\text { personnel entry for recovery operations } \\
\text { Master-slave manipulators not required due to ability for personnel } \\
\text { entry for recovery operations }\end{array}$ \\
\hline $\begin{array}{l}\text { Control Operations } \\
\text { (control and data management) }\end{array}$ & $\begin{array}{l}\text { Local control of all equipment with no supervisory control system } \\
\text { Operating gallery no longer needed } \\
\text { Paper procedural control over cell operation } \\
\text { K-plug and cameras not required } \\
\text { Sealed cabling system not required }\end{array}$ \\
\hline Maintain/Repair Equipment & $\begin{array}{l}\text { Equipment locally serviced, repaired and tested } \\
\text { Glovebox or testing work tables not required } \\
\text { Computer controlled glovebox handling system not required } \\
\text { Unshielded transition area for personnel cell entry }\end{array}$ \\
\hline Mitigate Weld Stresses & Equipment maintained locally \\
\hline
\end{tabular}




\subsubsection{Alternative 4-Manual System}

The manual system alternative is tailored to operate in a low radiation and low contamination environment. In order to minimize cost, the equipment would be designed with no automation. Equipment and materials would be deployed manually or with lifting assistance. The design would not have a centralized control system; local manual control would be implemented. Data collection would be manual. Personnel would conduct all operations in the closure cell on a continual basis.

The key design features unique to a specific system function are given in Table 6 below.

Table 6. Alternative 4: Manual system.

\begin{tabular}{|l|l|}
\hline \multicolumn{1}{|c|}{ System Function } & \multicolumn{1}{c|}{ Key Design Features } \\
\hline Inert Waste Package & $\begin{array}{l}\text { Manual manipulation of purge port plug } \\
\text { Inner lid filtration not required } \\
\text { In-line filtration in the purge and backfill line not required }\end{array}$ \\
\hline $\begin{array}{l}\text { Leak Test Inner Lid } \\
\text { Seal Weld }\end{array}$ & Manually operated valves will be implemented \\
\hline Weld Lids & $\begin{array}{l}\text { Hand-held torch manually operated } \\
\text { Radically different welding techniques and procedures due to the } \\
\text { switch to manual welding }\end{array}$ \\
\hline Inspect Welds & $\begin{array}{l}\text { Manually operated hand-held transducers } \\
\text { Radically different inspection techniques and procedures due to the } \\
\text { switch to manual operation }\end{array}$ \\
\hline Repair Defects & $\begin{array}{l}\text { Hand-operated grinder for weld repair } \\
\text { Hand-held vacuum system for swarf collection }\end{array}$ \\
\hline Handle Materials/Equipment & $\begin{array}{l}\text { Remote handling system manipulator not required due to ability for } \\
\text { personnel entry for recovery operations } \\
\text { Master-slave manipulators not required due to ability for personnel } \\
\text { entry for recovery operations }\end{array}$ \\
\hline $\begin{array}{l}\text { Control Operations } \\
\text { (control and data management) }\end{array}$ & $\begin{array}{l}\text { No supervisory control system } \\
\text { Manual data archiving } \\
\text { Operating gallery no longer needed } \\
\text { Paper procedural control over cell operation } \\
\text { K-plug and cameras not required } \\
\text { Sealed cabling system not required }\end{array}$ \\
\hline $\begin{array}{l}\text { Equipment locally serviced, repaired and tested } \\
\text { Glovebox or testing work tables not required } \\
\text { Computer controlled glovebox handling system not required } \\
\text { Unshielded transition area for personnel cell entry }\end{array}$ \\
Equipment maintained locally \\
\hline Mepair Equipment
\end{tabular}




\subsection{Ranking of Alternatives}

Each alternative was compared to the evaluation criteria and assigned a score using a scale of 1 to 10 , with a score of ten indicating best fulfillment of the criteria. The scores were determined by collective agreement between the value engineering evaluation team members. Each score was then multiplied by the corresponding criteria weighting factor. The results are summarized in Table 7, indicating the nonradiation-hardened remote automated system is the optimum alternative. Table 8 summarizes the complete evaluation showing the individual scores, explanations for the scores, the criteria weighting factors, and the final weighted ranking of the four alternatives.

Table 7. Scores and ranking results summary.

\begin{tabular}{|l|c|c|}
\hline \multicolumn{1}{|c|}{ Alternative } & $\begin{array}{c}\text { Total of Weighted } \\
\text { Scores }\end{array}$ & Desirability Ranking \\
\hline $\begin{array}{l}\text { Radiation-Hardened Remote } \\
\text { Automated System (Baseline) }\end{array}$ & 859 & 2 \\
\hline $\begin{array}{l}\text { Nonradiation-Hardened Remote Automated } \\
\text { System }\end{array}$ & 891 & 1 \\
\hline Semi-automated System & 591 & 3 \\
\hline Manual System & 342 & 4 \\
\hline * Maximum possible score 1000. & \multicolumn{2}{|l|}{} \\
\hline
\end{tabular}

The recommended alternative for closing a waste package with a shielded TAD canister is a nonradiation-hardened remote automated system. The radiation-hardened system is close in scoring primarily because the safety, ALARA, and throughput are high with a remote automated system. These three criteria are also weighted most heavily. The nonradiation-hardened system received a higher score than the radiation-hardened system in three areas; time required prior to demonstration, operational labor costs, and equipment costs. The radiation-hardened system is capable of operating in the low radiation and contamination environment; however, it has features that are not necessary for these conditions. As the results indicate for the two systems, the nonradiation-hardened version would be the least costly and quickest to demonstrate.

Comparing the two automated alternatives to the two less automated alternatives shows a clear advantage of automation with respect to safety, throughput, reliability, and quality. Equipment costs and time to demonstration are rated higher for the semi-automated and manual systems, but these two criteria are insufficient to offset the benefits offered by the automated alternatives. 


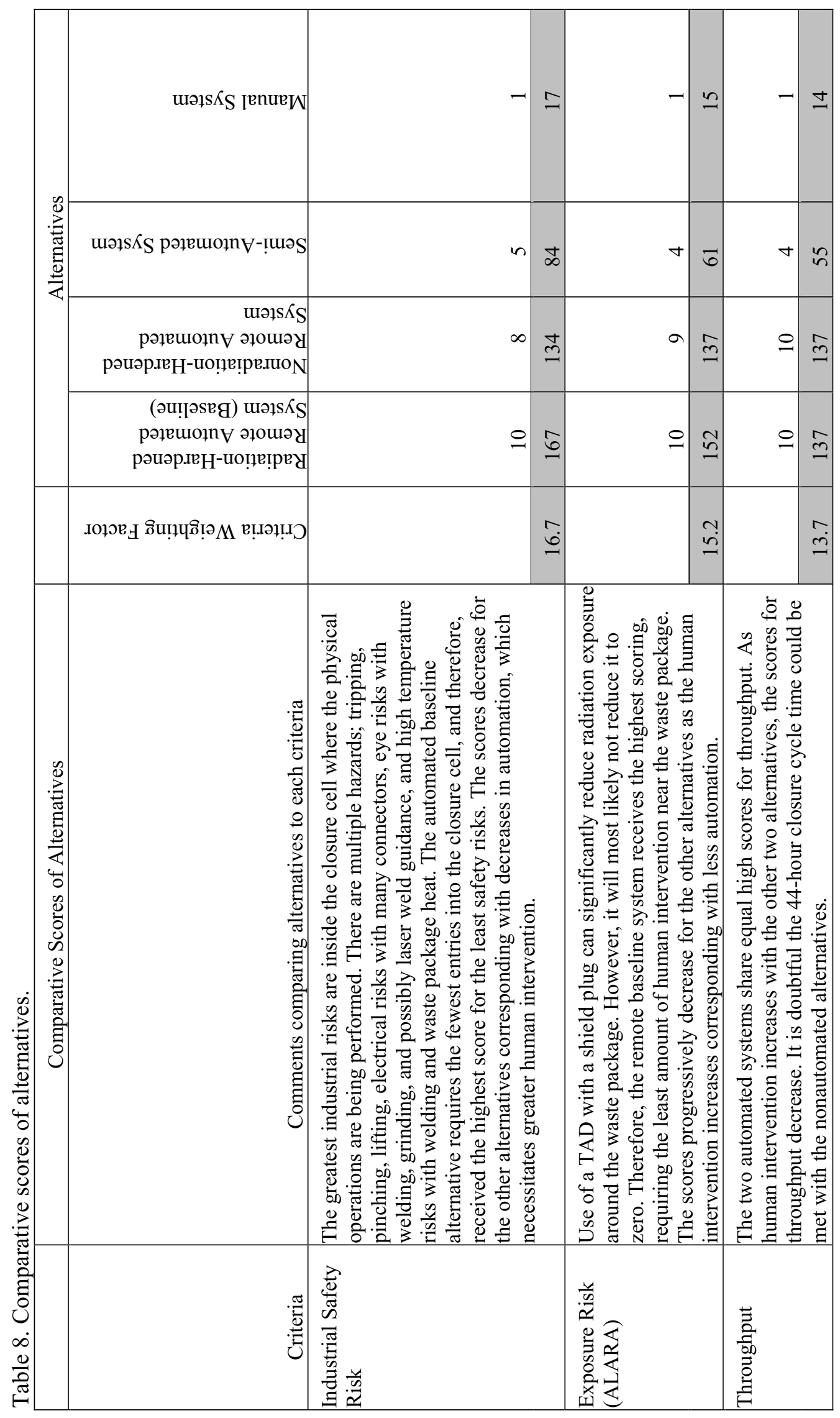




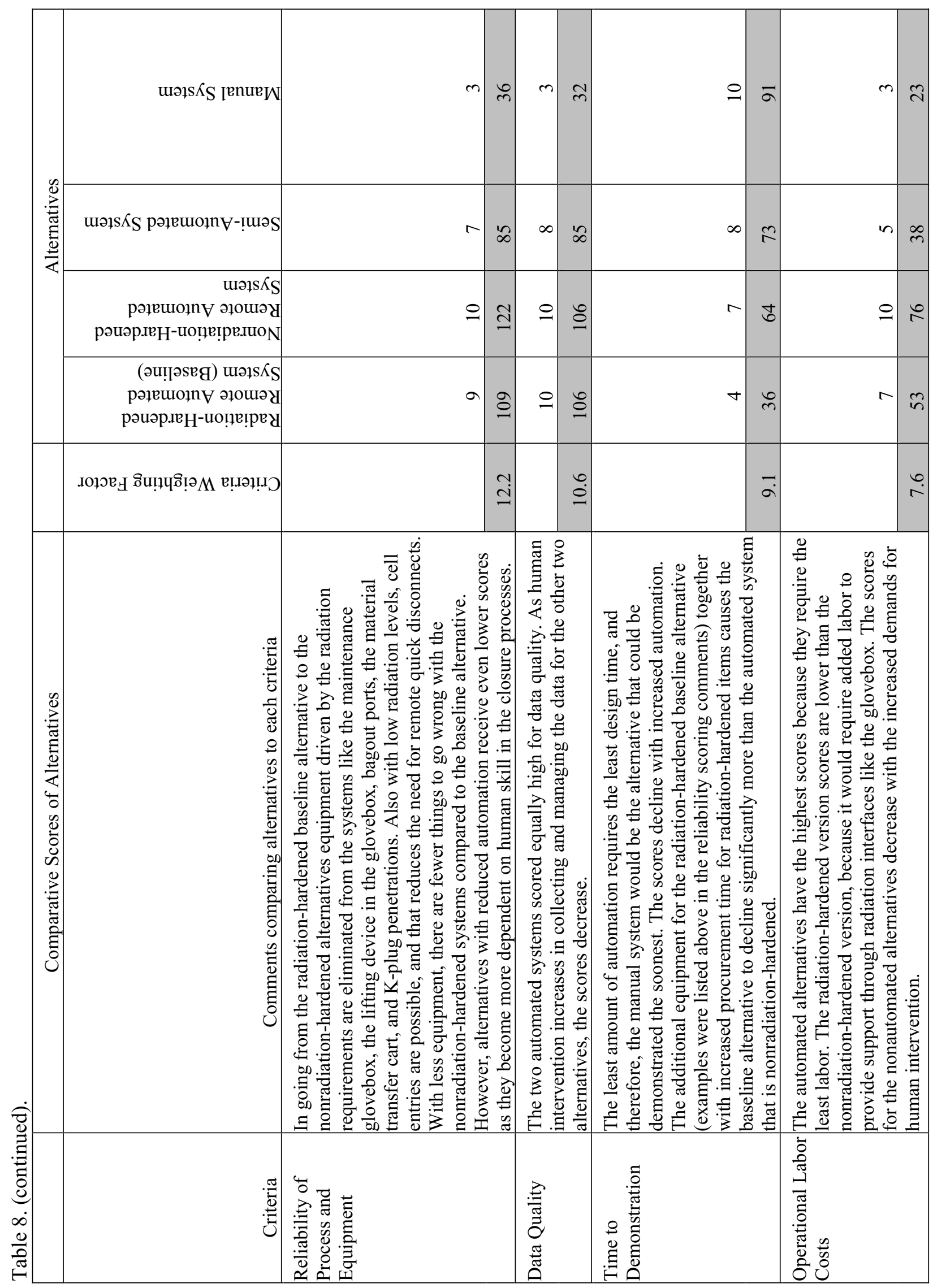




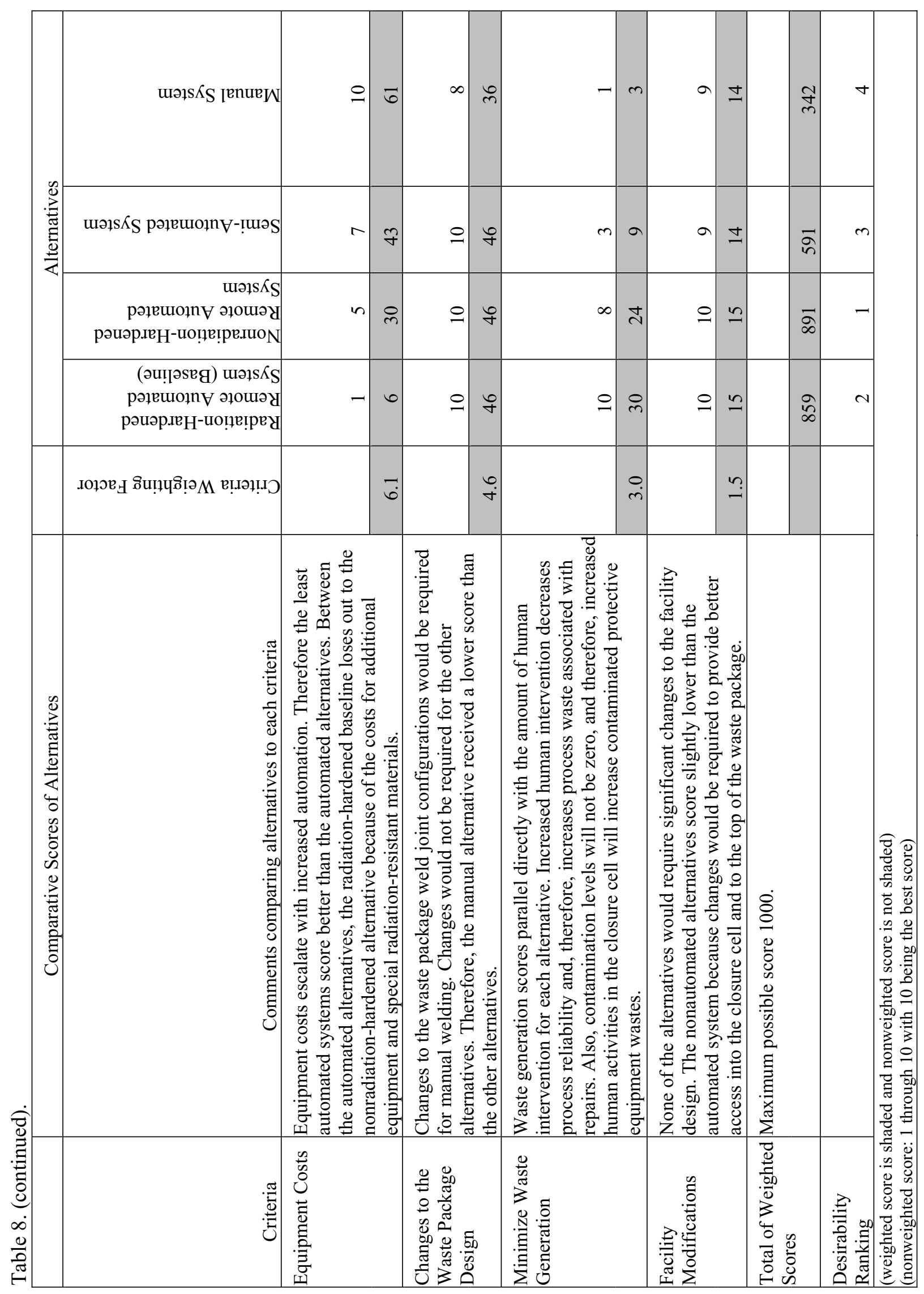




\section{RESPONSES TO QUESTIONS FROM OCRWM}

OCRWM directed that the value engineering team consider five questions during their evaluation. These questions were used during the information gathering phase and in determining the evaluation criteria and alternatives. The team's responses to these questions are below.

\section{Is remote radiation-hardened welding equipment required?}

Remote radiation-hardened welding equipment is not required if a TAD canister is used. However, a remotely automated system is preferred to optimize throughput, improve process reliability, ensure weld quality, and reduce operational labor costs.

\section{How does the current approach compare with similar canisters in the industry?}

The primary difference between the waste package used for disposal at the repository and the canisters used by utilities is that the utility canisters are for short-term storage and transportation only while the waste package is used for long-term disposal in the repository. Canisters used by the utility industry today are not designed and licensed for long-term disposal and require that the fuel in them be repackaged into another package, i.e., the waste package currently designed for the repository.

Because the waste package is used for long-term disposal, the requirements for closure are more complex than those for utility storage and transportation. For example, the waste package includes a three-lid configuration and multiple steps for placement while the utility industry uses a two-lid system. Closure of the waste package requires welding of two different materials while the industry canisters contain only one type of material. In addition, closure of utility canisters requires only partial penetration welds while full thickness welds are required for closure of the waste package. Finally, nondestructive examination of the waste package welds requires volumetric inspections while the utility industry is only required to perform surface inspections.

\section{What portions of the INL work that is already completed would be applicable to welding a waste package loaded with a TAD, and what portions have no further purpose?}

The current baseline is applicable to closure of a waste package loaded with a TAD canister. However, nonradiation-hardened equipment is preferred because of reduction in cost and increased availability. In addition, certain specialized equipment could be simplified (glovebox confinement structure) or eliminated (transfer tunnel shielding, master-slave manipulators).

Although radiation-hardened equipment is not required, the following items have already been purchased. They would be applicable to Alternative 1, but are not needed for the recommended Alternative 2.

- One welding radiation-hardened robot (2 robots required)

- Radiation-hardened cameras

- Master-slave manipulators

- One welding end effector (2 end effectors are required). 
The applicability of the waste package closure system to the closure of a TAD is strongly dependent on the design of the TAD. Collaboration with the INL Waste Package Closure System Design Team and those designing the TAD would ensure that the waste package closure system could be used to close a TAD.

\section{How quickly could a welding demonstration project occur with a TAD?}

Development of the recommended closure system (nonradiation-hardened/automated system) will require about 28 months once the project is reinstated. A demonstration with a waste package loaded with a TAD canister could be performed at that time.

\section{What lessons learned are available from industry and from the rest of the DOE complex that the OCRWM should take into consideration?}

- A production type facility that uses a system similar to the waste package closure system has not been implemented in industry or DOE. However, automation appears to be important to ensure production schedules, minimize personnel exposure, and improve performance. Semi-automated welding with manual inspection has proved to be time and labor intensive on the Three Mile Island project and the Naval Reactors Facility. The INL 3100 cubic meters real-time radioscopy system was manual with no programming functions. Automating the system with microprocessor controls increased productivity under finer control parameters for the inspection of 55-gallon drums. Finally, observations from manual welding projects reveal significantly more distorted welds than those produced from automated systems.

- INL staff have visited sites and viewed equipment operations at AMI, PCI, Jetline, AMET, and Berkeley Control to determine their capability to close the waste package under the current design. Observations showed:

- Equipment at these firms was not flexible enough to weld three lids and varying diameters

- Existing equipment designs could not weld both lids and the purge port cap.

- Existing equipment did not include weld dressing and inspection capabilities.

- The existing equipment at these firms could not handle the high radiation levels.

- The companies could not meet current throughput requirements with existing methods.

- Existing equipment at these firms does not include nondestructive examination capabilities. 


\section{SUMMARY}

OCRWM announced their intention to have the commercial utilities package spent nuclear fuel in shielded TAD canisters prior to shipment to the Yucca Mountain repository. This changes the conditions used as a basis for the design of the waste package closure system to a low radiation, low contamination area. A value engineering study was completed to evaluate possible modifications to the existing closure system using the revised requirements. Four alternatives were identified and evaluated against a set of weighted criteria. They are (1) a radiation-hardened, remote automated system (the current baseline); (2) a nonradiation-hardened, remote automated system (with personnel intervention if necessary); (3) a semiautomated system with personnel access for routine manual operations; and (4) a nonradiation-hardened, fully manual system with full-time personnel access. The recommended alternative is a nonradiationhardened, remote automated system. It is less expensive and less complex than the current baseline system because nonradiation-hardened equipment can be used and some contamination control equipment is no longer needed. In addition, the inclusion of remote automation ensures throughput requirements are met, provides a more reliable process, and provides greater protection for employees from industrial accidents and radiation exposure than the semi-automated or manual systems.

OCRWM also requested that the following specific questions be considered as part of the value engineering study.

1. Is remote radiation-hardened welding equipment required?

It was determined that nonradiation-hardened equipment could be used to close the waste packages, assuming that the use of a shielded TAD canister reduces the radiation field in the closure cell to an acceptable level $(<40 \mathrm{mrem} / \mathrm{hr})$.

2. How does our approach compare with similar canisters in the industry?

Closure of the waste package is significantly more complex than typical canisters. The waste package has three lids made from two materials of varying diameters rather than the typical two lids of one material and size. The system must, therefore, be capable of changing wire material and welding parameters during the closure operation. It must also have the flexibility to access varying diameters, including a small central cap over the purge opening. Other complex requirements of the waste package design include the weld joint configuration (full thickness welds versus partial penetration) and more extensive nondestructive examinations (volumetric versus surface inspections only). Industry does not typically have stringent production schedules, whereas Yucca Mountain must meet aggressive throughput requirements. This drives many of the design features that are different from industry, in particular the remote automation.

3. What portions of the INL work that is already completed would be applicable to welding a TAD or waste package loaded with a TAD, and what portions have no further purpose?

The current baseline is applicable to closure of a waste package loaded with a TAD canister. However, nonradiation-hardened equipment is preferred because of reduction in cost and increased availability. In addition, certain specialized equipment could be simplified (glovebox confinement structure) or eliminated (transfer tunnel shielding, master-slave manipulators). 
The applicability of the closure system to seal a TAD canister is strongly dependent on the design of the canister. Collaboration between the INL design team and those designing the TAD canister would ensure that the waste package closure system could be used to seal a TAD canister.

4. How quickly could a welding demonstration project occur with a TAD?

Development of the recommended closure system (nonradiation-hardened/automated system) will require about 28 months once the project is reinstated. A demonstration with a waste package loaded with a TAD canister could be performed at that time.

5. What lessons learned are available from industry and from the rest of the DOE complex that OCRWM should take into consideration?

A production type facility that has requirements similar to the waste package closure system has not been implemented in industry or DOE. However, experience has shown that remote automation is important to ensure high throughput schedules, minimize personnel exposure, and improve quality. Semiautomated welding with manual inspection proved to be time and labor intensive on the Three Mile Island fuel repackaging project and the Naval Reactors Facility. Through automation of a previously manual system, the INL low-level waste real-time radioscopy system increased productivity. Observations from manual welding projects in the commercial industry reveal significantly more distorted welds than those produced by automated systems.

The nonradiation-hardened, remote automated system meets the requirements for closure of a waste package loaded with a TAD canister. It simplifies the existing system where applicable while minimizing redesign efforts and still meeting the reliability and throughput needs of Yucca Mountain. 